\title{
Effect of climate on recruitment success of Atlantic Iberian sardine Sardina pilchardus
}

\author{
Cástor Guisande $^{1, *}$, José Manuel Cabanas ${ }^{2}$, Alba Ruth Vergara ${ }^{1}$, Isabel Riveiro ${ }^{1}$ \\ ${ }^{1}$ Facultad de Ciencias del Mar, Universidad de Vigo, Lagoas-Marcosende, 36200 Vigo, Spain \\ ${ }^{2}$ Instituto Español de Oceanografía, Centro Costero de Vigo, Aptdo. 1552, 36280 Vigo, Spain
}

\begin{abstract}
The aim of this study was to determine how climatic (North Atlantic Oscillation winter index, NAO, December through March), oceanographic (upwelling intensity, turbulence, water column stability and larval offshore transport) and biotic (adult abundance) factors affect recruitment success of Sardina pilchardus off the northwest coast of the Iberian peninsula. Annual sardine juvenile landings in the port of Vigo (Spain) from 1980 to 2000 were used as an indicator of sardine recruitment success. Ekman transport along the $x$-axis $\left(Q_{X}\right)$ in February $\left(Q_{X} F\right)$, from March to April $\left(Q_{X} \mathrm{MA}\right)$, from May to August over the preceding year $\left(Q_{X} \mathrm{MJJA}\right)$, and NAO explained $86 \%$ of the variance observed in catches of sardine juveniles. Due to the north-south orientation of the west coast of the Iberian peninsula, upwelling intensity and larval drift offshore are higher the lower the $Q_{\mathrm{x}}$. Landings of sardine juveniles were higher in those years with moderate $Q_{X} F_{\text {, high }} Q_{X} \mathrm{MA}$, low $Q_{X}$ MJJA and low NAO values. There was a dome-shaped relationship between sardine juvenile landings and $Q_{\mathrm{X}} \mathrm{F}$. Under both high and low $Q_{\mathrm{X}}$ conditions, the upper layer is strongly mixed. Therefore, the reduced recruitment success observed at both high and low $Q_{\mathrm{X}} \mathrm{F}$ values could be due to a stratified upper layer in February enhancing primary production during the spring bloom and, hence, larval food availability. As March and April are the main spawning periods for sardine in this area, the reduced sardine recruitment success observed as $Q_{X}$ MA decreased was probably due to the transport offshore of eggs and larvae. In this area the main upwelling season is from May to August. Therefore, the positive relationship between upwelling intensity from May to August and nutrient concentration in surface layers could explain why landings of sardine were higher when $Q_{X} \mathrm{MJJA}$ over the preceding year was lower. Finally, in years with low NAO sardine recruitment success was higher. When NAO is lower than average, the winter/spring temperatures are warmer and transport offshore is lower.
\end{abstract}

KEY WORDS: Sardine $\cdot$ Recruitment success $\cdot$ Larval transport offshore $\cdot$ Upwelling $\cdot$ NAO $\cdot$ Water column stability $\cdot$ Turbulence

\section{INTRODUCTION}

Food availability affects larval survival (Theilacker 1986, Canino et al. 1991, Kitahara \& Matsuura 1995). Food quantity and quality must be appropriate at the time of the spawning period to assure larval survival (Hjort 1914, Cushing 1975, Lasker 1978). In addition to food quantity and quality, food aggregation also seems

*E-mail: castor@uvigo.es to be important for larval condition. Long periods of stable oceanic conditions seem to lead to fine-scale particle aggregations, enhancing food availability and, hence, larval survival (Lasker 1981); this would explain why recruitment of pelagic fishes is affected by turbulence of the water (Cury \& Roy 1989, Borja et al. 1996) and/or the existence of time/space windows within which turbulence does not exceed critical values (Peterman \& Bradford 1987, Cury \& Roy 1989). Finally, offshore transport can have a profound detrimental effect on larval survival by carrying eggs and larvae to

(C) Inter-Research $2001 \cdot$ www.int-res.com 
areas where there is not enough food to survive (Bailey 1981, Parrish et al. 1981). Food quantity and quality, turbulence in the surface layers and larval drift offshore are clearly influenced by the direction and speed of the wind, and, probably for this reason, models based on wind speed and direction explain a high proportion of the recruitment variability observed in pelagic fishes (Belvèze \& Erzini 1983, Sinclair et al. 1985, Dickson et al. 1988, Wyatt \& Pérez-Gándaras 1988, Cury \& Roy 1989, Borja et al. 1996).

Both year-class strength of sardines Sardina pilchardus, which is an indicator of sardine recruitment success, and annual catches of $S$. pilchardus, west of Iberian peninsula and northwest of Africa, seem to be also related with hydroclimatic factors, although contradictory results have been obtained. Belvèze \& Erzini (1983) found a positive relationship between catches of the Moroccan sardine $S$. pilchardus and upwelling intensity. Wyatt \& Pérez-Gándaras (1988) also showed that the year-class strength of sardines in the coastal waters off Portugal and western Galicia (Spain) were positively correlated with upwelling intensity. However, Dickson et al. (1988) showed a negative relationship between Iberian sardine catches, 1950 to 1984, and the average April upwelling index at Porto (Portugal) over the preceding $3 \mathrm{yr}$. These contradictory results can be explained because upwelling may influence larval success in 2 different ways (Wyatt \& Pérez-Gándaras 1988, Cury \& Roy 1989). On the one hand, increased upwelling rates can enhance primary production due to the nutrient-rich, subsurface waters which are brought to the euphotic layers, hence the positive relationship between upwelling and recruitment success. However, increased upwelling leads to an increase in offshore larval drift, which may reduce recruitment success by dispersing the larvae to areas with low quantities of and/or low-quality food. Increased upwelling could also produce highly mixed layers, which could have a detrimental effect on larval food availability due to light limitation.

Despite the contradictory results mentioned above, all studies agree that recruitment success of Sardina pilchar$d u s$, in western coastal waters of the Iberian peninsula is affected by abiotic factors, mainly speed and direction of prevailing winds during the spawning season, but it is not clear how these abiotic factors affect the year-class strength of sardine. The aim of this study was to elaborate a model to explain how hydroclimatic factors affect the recruitment variability of sardine off the northwest coast of the Iberian peninsula.

\section{METHODS}

Recruitment estimation. Robles et al. (1992) showed that annual landings of Atlantic Iberian sardine juveniles (body length between 8 and $12 \mathrm{~cm}$ ), in southern Galician ports (northwest of Spain) from 1980 to 1989, were significantly correlated with virtual population analysis recruitment estimates, calibrated by acoustic surveys and the catch per unit effort of the fishery. One of the most important Galician ports, in terms of sardine landings, is Vigo (southwestern Galicia, Spain), with a mean \pm SD percentage of the total annual catch landed in Galicia from 1980 to 1989 of $57.7 \pm 24.2 \%$. Therefore, juvenile sardine landings in Vigo can be used as an indicator of sardine recruitment success off the northwest Iberian peninsula.

Table 1 shows total annual landings of adults and juveniles of sardine in the port of Vigo from 1980 to 2000. The annual catches of sardine were not corrected by effort of the fishery because (1) the number of nets de-

Table 1. North Atlantic Oscillation winter index (NAO), the mean daily Ekman transport rates along the $x$-axis (in $\mathrm{m}^{3} \mathrm{~s}^{-1} \mathrm{~km}^{-1}$ ) in February $\left(Q_{X} \mathrm{~F}\right)$, in March to April $\left(Q_{X} \mathrm{MA}\right)$ and from May to August $\left(Q_{X} \mathrm{MJJA}\right)$, and annual landings of adults and juveniles of Sardina pilchardus (in $\mathrm{t}$ ) in the port of Vigo (Spain) from 1979 to 2000

\begin{tabular}{|rrrrrrr|}
\hline Year & NAO & $Q_{X} \mathrm{~F}$ & $Q_{X} \mathrm{MA}$ & $Q_{X}$ MJJA & $\begin{array}{c}\text { Adult } \\
\text { landings }\end{array}$ \\
\hline 1979 & & & & & & \\
1980 & -2.25 & 570.0 & -90.9 & -455.0 & & \\
1981 & 0.56 & 257.6 & -76.9 & 1.4 & 5578.6 & 2820.4 \\
1982 & 2.05 & -61.0 & 566.6 & -426.3 & 6648.4 & 2922.0 \\
1983 & 0.80 & 787.5 & -240.8 & -230.6 & 10078.0 & 62.2 \\
1984 & 1.62 & -170.7 & 17.7 & -194.1 & 4746.7 & 4407.7 \\
1985 & -0.63 & 117.5 & 5.4 & -622.9 & 6844.3 & 3857.0 \\
1986 & 0.50 & 324.5 & -408.5 & -391.6 & 5407.2 & 259.6 \\
1987 & -0.75 & 374.4 & 222.3 & -451.5 & 3533.9 & 4493.8 \\
1988 & 0.72 & 192.7 & -153.0 & -233.0 & 3836.3 & 255.6 \\
1989 & 5.08 & 184.0 & 5.3 & -448.4 & 2534.3 & 623.3 \\
1990 & 3.96 & 1269.0 & -436.5 & -336.4 & 2958.9 & 772.2 \\
1991 & 1.03 & 185.5 & -50.4 & -436.9 & 833.6 & 3459.1 \\
1992 & 3.28 & 129.3 & -389.6 & -278.2 & 2621.3 & 1400.9 \\
1993 & 2.67 & -407.1 & -47.6 & -267.4 & 3252.7 & 343.4 \\
1994 & 3.03 & 1061.6 & -209.0 & -207.9 & 3280.8 & 268.9 \\
1995 & 3.96 & 629.7 & -257.6 & -434.8 & 3281.7 & 283.8 \\
1996 & -3.78 & -470.9 & 176.0 & -342.9 & 2873.8 & 366.4 \\
1997 & -0.20 & 707.9 & -154.5 & -78.5 & 3372.3 & 486.3 \\
1998 & 0.72 & 48.6 & -49.7 & -393.0 & 893.1 & 547.6 \\
1999 & 1.70 & -343.1 & 42.7 & -139.3 & 1323.8 & 738.8 \\
2000 & 2.80 & 248.9 & 12.2 & -24.6 & 1559.9 & 485.0 \\
& & & & & & \\
\hline
\end{tabular}


ployed per vessel, (2) the kind of vessels and (3) the number of vessels in the port of Vigo fishing in this area (around 20 vessels) remained relatively constant from 1980 to 2000. Fig. 1 shows monthly landings of sardine juvenile from 1992 to 2000. The main spawning season of sardine in this area is between February and April, with a smooth peak in September through October (Ferreiro \& Labarta 1988, Riveiro et al. 2000). As juveniles are caught approximately 5 or 6 mo after hatching, the first cohorts spawned in autumn and in spring are caught approximately in January/February and June/July, respectively. Therefore, there are 2 annual peaks in the yield of juveniles in winter and summer (Fig. 1). The latest cohorts are caught in November/December. Therefore, the combined monthly catch from January to December is a good indicator of sardine recruitment success in this area.

Ekman transport. Daily Ekman transport at $43^{\circ} \mathrm{N}$, $11^{\circ} \mathrm{W}$ were calculated following the methodology described by Bakun (1973) and adapted for the Iberian peninsula by Lavín et al. (1991):

$$
Q_{X}=\frac{\tau_{Y}}{f \rho} 1000 \quad Q_{Y}=\frac{-\tau_{X}}{f \rho}
$$

where $Q_{X}$ and $Q_{Y}$ represent the Ekman transport rates along the $x$ - and $y$-axes (in $\left.\mathrm{m}^{3} \mathrm{~s}^{-1} \mathrm{~km}^{-1}\right), f=9.94 \times 10^{-5}$ $\mathrm{s}^{-1}$ (Coriolis factor), $\rho=1025 \mathrm{~kg} \mathrm{~m}^{-3}$ (water density) and $\tau_{x}$ and $\tau_{y}$ are the wind stress over the sea, which were calculated by the following equations:

$$
\tau_{x}=\rho_{\mathrm{a}} C_{\mathrm{d}} \sqrt{u^{2}+v^{2} u} \quad \tau_{y}=\rho_{\mathrm{a}} C_{\mathrm{d}} \sqrt{u^{2}+v^{2} V}
$$

where $\rho_{\mathrm{a}}=1.2 \mathrm{~kg} \mathrm{~m}^{-3}$ (air density), $C_{\mathrm{d}}=1.4 \times 10^{-3}$ (empiric resistance coefficient) and $u$ and $v$ are the $x^{-}$ and $y$-components of the geostrophic wind (in $\mathrm{m} \mathrm{s}^{-1}$ ):

$$
u=\frac{-\alpha \delta p}{f \delta y} \quad v=\frac{\alpha \delta p}{f \delta x}
$$

where $\alpha=1 / \rho_{a}=0.816 \mathrm{~m}^{3} \mathrm{~kg}^{-1}$ and $\delta p / \delta x$ and $\delta p / \delta y$ are the mean pressure gradient between the opposite borders in a $1^{\circ} \times 1^{\circ}$ cell centred at $43^{\circ} \mathrm{N}, 11^{\circ} \mathrm{W}$ obtained at 6,12 and $18 \mathrm{~h}$.

The northwestern Atlantic coast of the Iberian peninsula shows a north-south orientation, and, hence, northern winds produce offshore transport. The magnitude of offshore transport in the upper layer is considered to be an indication of the amount of water upwelled along the coast into the surface layers (Mann \& Lazier 1991) and, also to affect larval drift offshore (Bailey 1981, Parrish et al. 1981). Therefore, off the northwest coast of the Iberian peninsula Ekman transport along the $x$-axis $\left(Q_{X}\right)$ is a good indicator of both larval drift offshore and upwelling intensity (input of nutrients into the euphotic layers).

Turbulence. The energy transferred through the water column by the wind creates turbulence in the surface layers. Therefore, a wind-mixing index in the upper layer is usually calculated as the cube of wind speed (Bakun \& Parrish 1982). We used this index as an indicator of turbulence in the surface layers.

Water column stability. Monthly CTD data have been available since 1990 from a station located at $43^{\circ} 7.8^{\prime} \mathrm{N}, 9^{\circ} 7.5^{\prime} \mathrm{W}$, which is close to the place we selected Ekman transport to calculate rates, although the data for some months were missing as sampling was not carried out due to climatic conditions. The Brunt-Väisälä or buoyancy frequency equation $(N)$ was used to measure the strength of the density gradients:

$$
N=\sqrt{\frac{g d \rho}{\bar{\rho} d z}}
$$

where $\rho$ is the density at depth (in $\mathrm{kg} \mathrm{m}^{-3}$ ), $\bar{\rho}$ is the mean $\rho$ of the water column, $g$ is the acceleration due to gravity, $z$ is the depth and $d$ is the derivative. The integrated buoyancy frequency estimated by the trapezoid method was used as an indicator of stability of the water column $(S)$ :

$$
S=\frac{\stackrel{\substack{z_{n} \\ z_{1}}}{z_{n}} \mathrm{Ndz}}{\underset{z_{1}}{f} d z}
$$

Low values of $S$ indicate that the water column is mixed, whereas high values indicate that the water column is stratified.

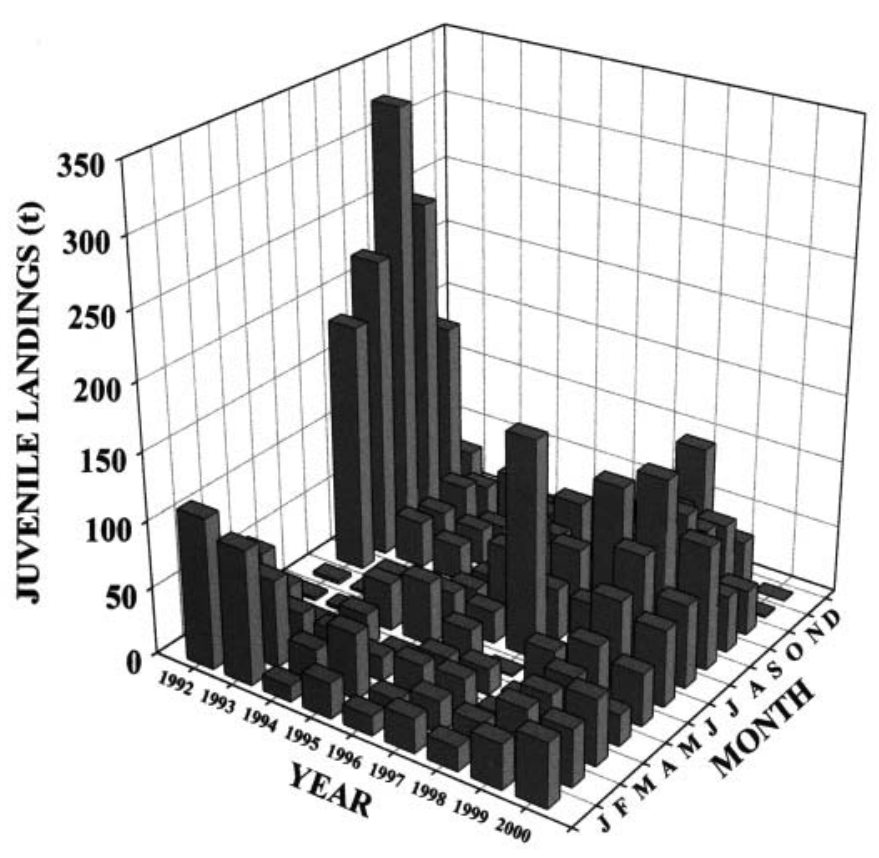

Fig. 1. Monthly juvenile landings of Sardina pilchardus (in t) in the port of Vigo from 1992 to 2000 


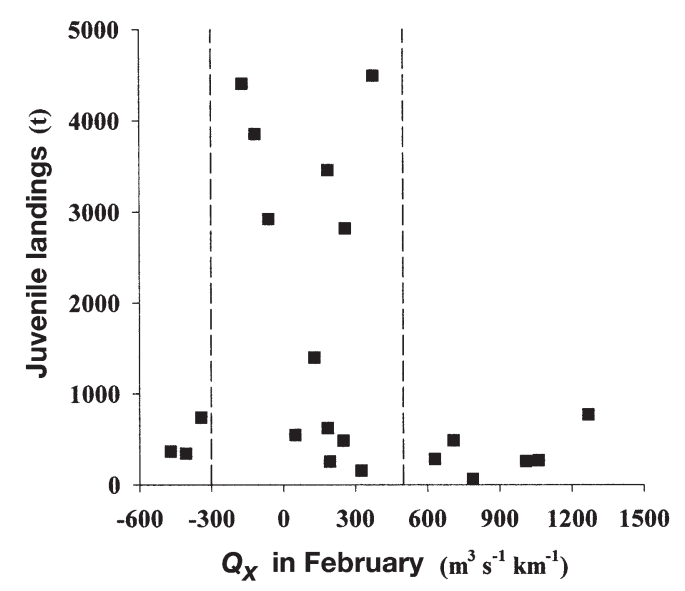

Fig. 2. Relationship between mean daily Ekman transport rates along the $x$-axis in February $\left(Q_{X} \mathrm{~F}\right.$, in $\left.\mathrm{m}^{3} \mathrm{~s}^{-1} \mathrm{~km}^{-1}\right)$ and total annual juvenile landings of Sardina pilchardus (in t) in the port of Vigo from 1980 to 2000. Dashed lines show Ekman transport of -300 and $500 \mathrm{~m}^{3} \mathrm{~s}^{-1} \mathrm{~km}^{-1}$

North Atlantic Oscillation winter index. The values of the North Atlantic oscillation winter (December through March) index (NAO), based on the difference of normalized sea level pressures between Lisbon (Portugal) and Stykkisholmur/Reykjavik (Iceland), were obtained from http://www.cgd.ucar.edu/cas/climind/ nao_winter.html (Hurrell 1995). The mean \pm SD of the NAO values from 1979 to 2000 (Table 1) is $1.54 \pm 2.02$.

Statistical methods. The SPSS program was used to estimate linear and non-linear regressions. As temporal series of recruitment studies can be influenced by autocorrelation (Marshall \& Frank 1999), the DurbinWatson test was used to determine whether there was autocorrelation between the time series:

$$
d=\frac{\sum_{t=2}^{W}\left[\left(y_{t}-\hat{y}_{t}\right)-\left(y_{t-1}-\hat{y}_{t-1}\right)\right]^{2}}{\sum_{t=1}^{W}\left(y_{t}-\hat{y}_{t}\right)^{2}}
$$

where $w$ is the number of years, and $y$ and $\hat{y}$ are the observed and predicted annual juvenile landings for each year $t$, respectively.

\section{RESULTS}

From all variables considered (adult landings, turbulence, water column stability, NAO, monthly $Q_{X}$ and $Q_{Y}$ and the combined mean $Q_{X}$ and $Q_{Y}$ of several consecutive months), only NAO, the mean $Q_{X}$ in February $\left(Q_{X} \mathrm{~F}\right)$, the mean $Q_{X}$ from March to April $\left(Q_{X} \mathrm{MA}\right)$, and the mean $Q_{X}$ from May to August over the preceding year $\left(Q_{X}\right.$ MJJA) (Table 1$)$ were significantly related with annual landings of juvenile sardines.

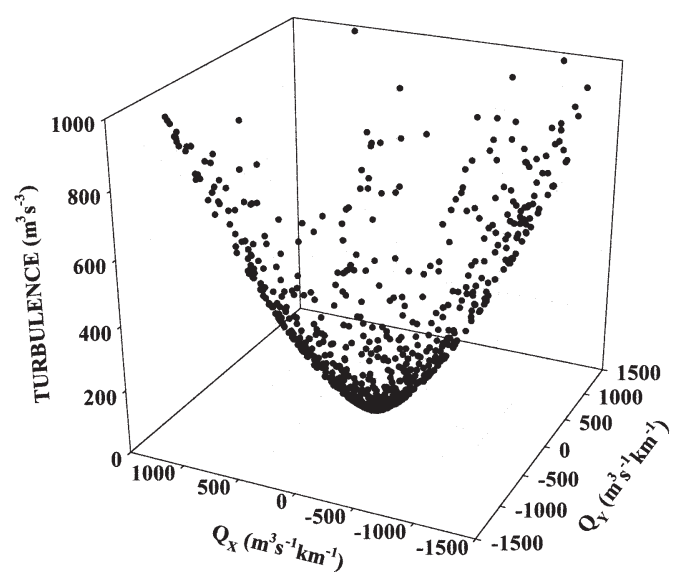

Fig. 3. Relationship between daily turbulence (in $\mathrm{m}^{3} \mathrm{~s}^{-3}$ ) and daily Ekman transports along the $x$-axis $\left(Q_{X} F\right.$, in $\left.\mathrm{m}^{3} \mathrm{~s}^{-1} \mathrm{~km}^{-1}\right)$ and along the $y$-axis $\left(Q_{y} \mathrm{~F}\right.$, in $\left.\mathrm{m}^{3} \mathrm{~s}^{-1} \mathrm{~km}^{-1}\right)$ in February from 1980 to 2000

Fig. 2 shows that high annual landings of sardine were only observed in those years with $Q_{X} F$ values within -300 and $500 \mathrm{~m}^{3} \mathrm{~s}^{-1} \mathrm{~km}^{-1}$. For non-optimal $Q_{X} F$ values (lower than $-300 \mathrm{~m}^{3} \mathrm{~s}^{-1} \mathrm{~km}^{-1}$ and higher than $500 \mathrm{~m}^{3} \mathrm{~s}^{-1} \mathrm{~km}^{-1}$ ), the juvenile landings were low, with a mean \pm SD of $397.9 \pm 231.7$ t. As both Ekman transport and turbulence of the water are affected by the speed of the wind, there is a clear relationship between Ekman transport and turbulence (Fig. 3). Therefore, the low values of juvenile landings, under both low (lower than $-300 \mathrm{~m}^{3} \mathrm{~s}^{-1} \mathrm{~km}^{-1}$ ) and high (higher than $500 \mathrm{~m}^{3} \mathrm{~s}^{-1} \mathrm{~km}^{-1}$ ) $Q_{X} \mathrm{~F}$ values (Fig. 2), could be due to a high intensity of turbulent wind-mixing and/or the absence of time/space windows within which turbu-

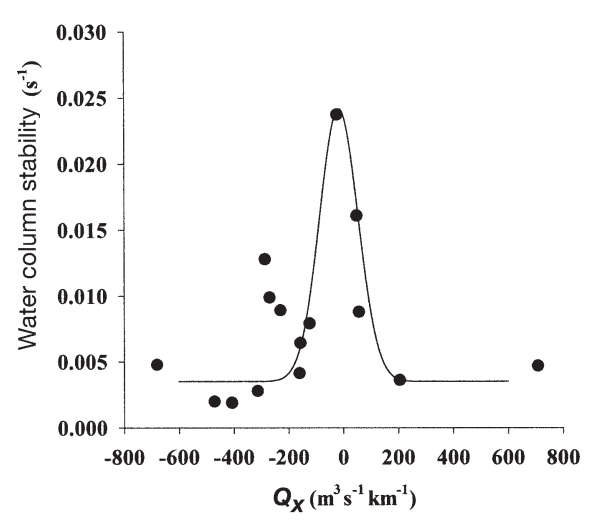

Fig. 4. Relationship between water column stability of the upper $40 \mathrm{~m}\left(S\right.$, in s$\left.{ }^{-1}\right)$ at the station located at $43^{\circ} 7.8^{\prime} \mathrm{N}, 9^{\circ} 7.5^{\prime} \mathrm{W}$ and mean daily Ekman transport rates along the $x$-axis $\left(Q_{X} F, Q_{X} M A\right.$ in $\mathrm{m}^{3} \mathrm{~s}^{-1} \mathrm{~km}^{-1}$ ) in February and March to April from 1990 to $2000 ; S=0.0035+\mathrm{e}^{0.000102^{*}\left[-38018.4+Q_{X^{-}}\left(Q_{\mathrm{X}}-15.549\right)^{2}\right]}, F_{1,13}=27.1$, $\mathrm{r}^{2}=0.67, \mathrm{p}<0.001$ 


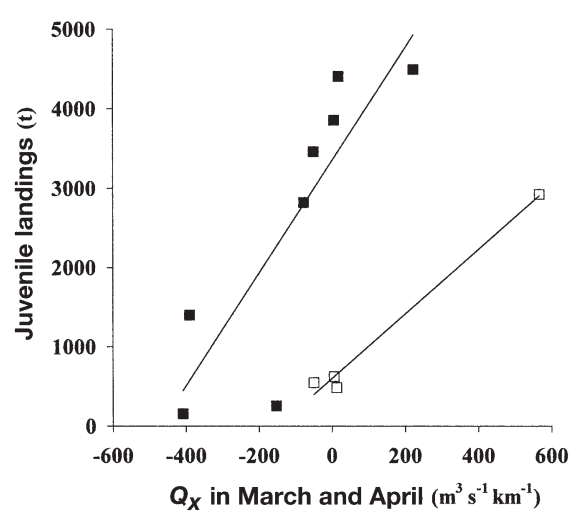

Fig. 5. Relationship between mean daily Ekman transport rates along the $x$-axis in March to April $\left(Q_{X} M A\right.$, in $\left.\mathrm{m}^{3} \mathrm{~s}^{-1} \mathrm{~km}^{-1}\right)$ and total annual juvenile landings of Sardina pilchardus (in t) in the port of Vigo from 1980 to 2000. Years with low values (घ, Eq. 1 shown in the text) or high values ( $\square$, Eq. 2 shown in the text) of North Atlantic Oscillation winter index and/or mean daily Ekman transport along the $x$-axis from May to August over the preceding year. Years with a mean Ekman transport along the $x$-axis in February lower than -300 or

higher than $500 \mathrm{~m}^{3} \mathrm{~s}^{-1} \mathrm{~km}^{-1}$ are not included in the figure

lence does not exceed critical values. However, an analysis of variance showed that there were no significant differences in the turbulence of the water in February $\left(F_{1,18}=0.1, \mathrm{p}>0.5\right)$ and in the combined Lasker events (defined as the number of 4 -d periods during which the wind speed did not exceed $6 \mathrm{~m} \mathrm{~s}^{-1}$ ) in February, March and April $\left(F_{1,18}=0.3, \mathrm{p}>0.5\right)$ between years with landings of juveniles equalling more or less than 2000 t. However, Fig. 4 shows that there was a relationship between $Q_{X}$ and stability of the water column. Therefore, the reduced juvenile landings at both low and high $Q_{X} F$ values (Fig. 2) might be due to strongly mixed layers, which could negatively affect primary production due to light limitation.

Fig. 5 shows that, in those years within the range of optimal $Q_{X} F$ values (within -300 and $500 \mathrm{~m}^{3} \mathrm{~s}^{-1} \mathrm{~km}^{-1}$ ), higher landings were obtained when $Q_{X} \mathrm{MA}$ was lower. Annual juvenile landings were significantly higher in years with low $\mathrm{NAO}$ and/or low $Q_{X} \mathrm{MJJA}$ than in years with high NAO and/or high $Q_{X}$ MJJA (Fig. 6), taking the covariate $Q_{X} \mathrm{MA}$ into account (ANCOVA, $F_{1,9}=19.9, \mathrm{p}=$ 0.002). The relationship between $Q_{X} \mathrm{MA}\left(\mathrm{in} \mathrm{m}^{3} \mathrm{~s}^{-1} \mathrm{~km}^{-1}\right)$ and juvenile landings ( $L$, in t) observed in years with low NAO and/or $Q_{\mathrm{X}} \mathrm{MJJA}$ is described by Eq. (1) $\left(F_{1,6}=15.1\right.$, $\mathrm{r}^{2}=0.72, \mathrm{p}=0.008$ ) and in years with high NAO and/or high $Q_{X}$ MJJA is described by Eq. (2) $\left(F_{1,2}=166.2, \mathrm{r}^{2}=\right.$ 0.99, $\mathrm{p}=0.006$ ) (Fig. 5):

$$
\begin{aligned}
& L=3346.8+7.11 \times Q_{X} \mathrm{MA} \\
& L=601.9+406 \times Q_{X} \mathrm{MA}
\end{aligned}
$$

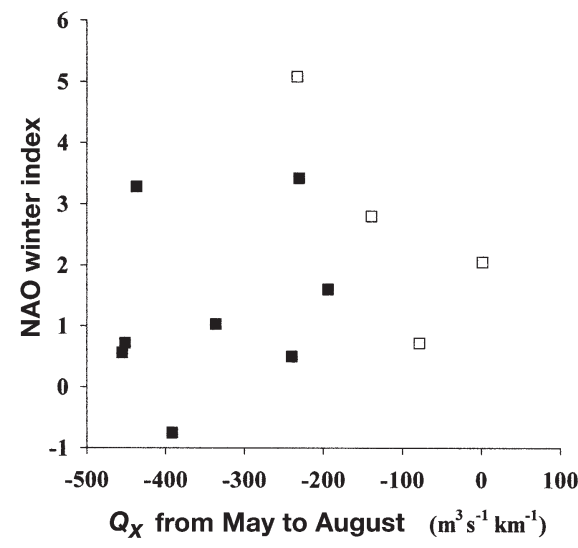

Fig. 6. North Atlantic Oscillation winter index (NAO) versus mean daily Ekman transport along the $x$-axis from May to August over the preceding year $\left(Q_{X}\right.$ MJJA, in $\left.\mathrm{m}^{3} \mathrm{~s}^{-1} \mathrm{~km}^{-1}\right)$ from 1980 to 2000. Symbols as described in Fig. 5. Years with a mean Ekman transport along the $x$-axis in February lower than -300 or higher than $500 \mathrm{~m}^{3} \mathrm{~s}^{-1} \mathrm{~km}^{-1}$ are not included in the figure

There was no autocorrelation in either Eq. (1) (Durbin-Watson test, $d=1.65>d_{\mathrm{u} 0.01[1]}=0.91, \mathrm{p}>0.05$ ) nor Eq. (2) (Durbin-Watson test, $d=2.42>d_{\mathrm{u} 0.01[1]}=$ $0.72, \mathrm{p}>0.05)$.

Fig. 7 shows that observed juvenile landings were similar to juvenile landings predicted by Eqs $(1 \& 2)$ in years within the range of optimal $Q_{X} F$ values, and those predicted by the mean annual juvenile landings (mean \pm SD: $397.9 \pm 231.7$ t) obtained in years when $Q_{X} \mathrm{~F}$ was not in the optimal range.

\section{DISCUSSION}

Along the Atlantic coast of Spain the most important spawning area for sardine is on the north coast of

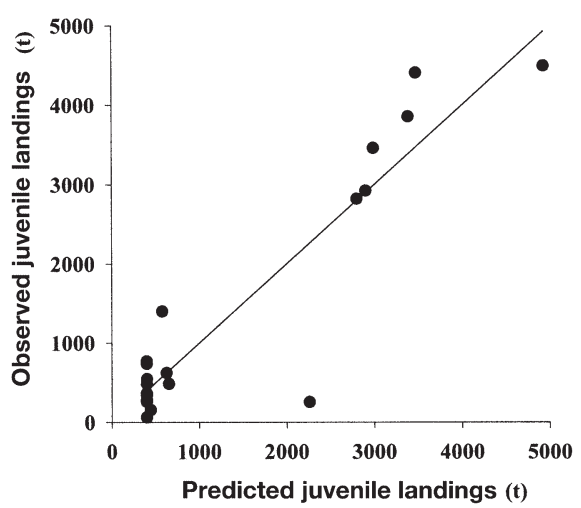

Fig. 7. Relationship between observed and predicted juvenile landings of Sardina pilchardus (in t) in the port of Vigo from 1980 to $2000\left(F_{3,17}=36.1, \mathrm{r}^{2}=0.86, \mathrm{p}<0.001\right.$, slope $=1.0$ and intercept $=-0.06$ ) 


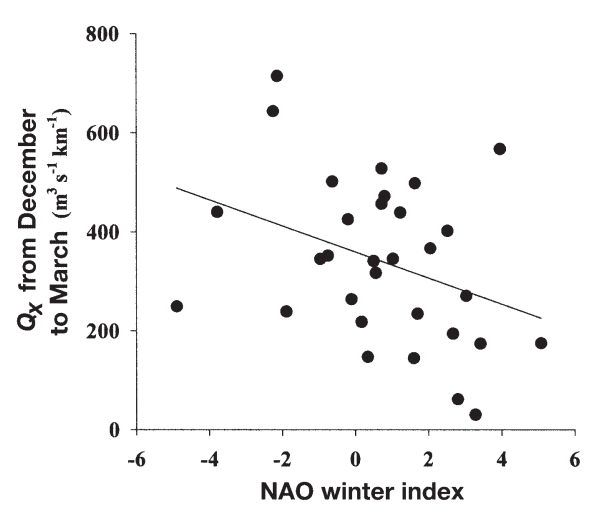

Fig. 8. Relationship between mean daily Ekman transport along the $x$-axis from 1 December to the end of March $\left(Q_{x}\right.$ in $\mathrm{m}^{3} \mathrm{~s}^{-1} \mathrm{~km}^{-1}$ ) and North Atlantic Oscillation winter index (NAO) 1970 to 2000 (slope different from $0 F_{1,29}=4.2$,

$$
\mathrm{p}=0.048)
$$

Spain (Cantabrian Sea), while little spawning takes place on the west coast of Spain (in Galician waters) (Solá \& Franco 1984, Chesney \& Alonso-Noval 1988, López-Jamar et al. 1995). For this reason, Robles et al. (1992) suggested that recruitment in Galicia mainly originates from spring spawning in the Cantabrian Sea and Chesney \& Alonso-Noval (1988) suggested that upwelling indices calculated for the west coast of the Iberian peninsula are unlikely to adequately assess the relationship between upwelling and recruitment of sardines along the Galician coast of Spain. However, Wyatt \& Pérez-Gándaras (1988) suggested that there is an important spawning area for the sardine on the northern Portuguese coastal platform. This hypothesis is supported by the high concentration of sardine eggs and larvae observed in the North of Portugal (Ré et al. 1990) and along the southwest Galician coast (close to the Spanish border) (Ferreiro \& Larbarta 1988, García et al. 1988, Riveiro et al. 2000). This spawning area for the sardine on the northern Portuguese coast could explain why catches of sardine along the Galician coast are related with upwelling calculated for the west coast of the Iberian peninsula and, moreover, supports the hypothesis that sardine juveniles captured in Galician waters originated from spawning areas along the north coast of Portugal (López-Jamar et al. 1995).

The results obtained in the present study agree with the optimal environmental window hypothesis proposed by Cury \& Roy (1989). A reduced recruitment success was observed at both high and low upwelling conditions in February, whereas recruitment success was higher under moderate upwelling conditions (Fig. 2). Upwelling intensity in February could be important to assure a high input of nutrients for the phytoplankton spring bloom. Therefore, the reduced recruitment success under low upwelling conditions in February (high $Q_{X} F$ ) might be explained as the result of a low input of nutrients into surface layers and, hence, reduced primary production. However, the relationship between $Q_{X}$ and water column stability (Fig. 4) seems to indicate that $Q_{X} F$ could also be important for sardine recruitment success, because the stability of the water column in February could affect primary production during the spring bloom. It is well known that stratified upper layers, before the onset of the spring bloom, enhance primary production. However, a strongly mixed layer could have a negative effect on primary production due to light limitation, and, hence, larvae could be food limited (Huntsman \& Barber 1977). Moreover, a strong mixed layer could negatively affect larval survival due to the dilution of food aggregations (Lasker 1981). Therefore, both high and low $Q_{X}$ in February could have a detrimental effect on year-class strength of sardine because such values are associated with a strongly mixed layer.

The results of this study also explain the contradictory results obtained between recruitment variability of Sardina pilchardus in the west of Iberian peninsula and upwelling intensity: a positive (Belvèze \& Erzini 1983, Wyatt \& Pérez-Gándaras 1988) and a negative (Dickson et al. 1988) effect of upwelling on sardine recruitment success. High upwelling intensity from May to August in this area increases nutrient concentration in surface water layers (Tenore et al. 1995) and, hence, favors primary production during the next spring; this would explain the negative relationship observed in the present study between $Q_{X}$ MJJA over the preceding year and sardine recruitment success. However, a high upwelling intensity during March and April has a negative effect on sardine recruitment success due to the offshore transport of eggs and larvae.

This study also has shown that lower than average NAO values enhanced sardine recruitment success; this can be explained in terms of the direction of prevailing winds in winter/spring under low and high NAO values. When NAO values are lower than average; equatorial trade winds from the south or southwest blow over the west coast of the Iberian peninsula, and, hence, the winter/spring temperatures are warmer than normal and the flow of water is towards the coast (Fig. 8). However, when NAO values are higher than average, westerly winds from the north and northwest affect the west coast of the Iberian peninsula, and, hence, the winter/spring temperatures are colder than normal and the flow of water is offshore (Fig. 8). The positive effect of low NAO values on sardine recruitment could, thus, be due to the low offshore drift of eggs and larvae (Fig. 8).

In agreement with other studies (see Lasker 1978), our model shows that the size of spawning stock is not important for the size of its resultant year-class. In the present study, the year-class strength of the sardine is 


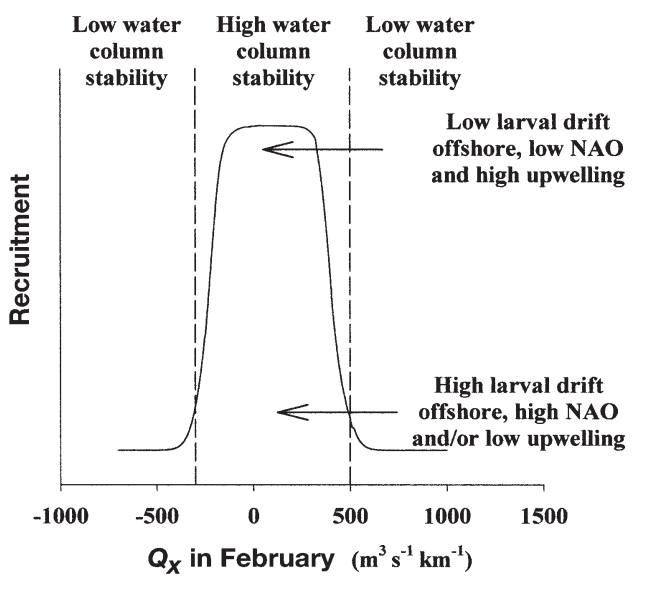

Fig. 9. Theoretical relationship between sardine recruitment success northwest of the Iberian peninsula and physical factors

mainly governed by hydroclimatic factors. However, it is important to point out that even under sub-optimal conditions (highly mixed layer, low upwelling and/or high larval drift offshore) a certain quantity of juvenile sardines is always caught (mean \pm SD: $397.9 \pm 231.7 \mathrm{t}$ ); this seems to indicate that a minimum population replacement is assured even in 'bad' years as long as fishing pressure does not push the adult stock below a minimum threshold value.

Fig. 9 summarizes the effect of physical factors on recruitment success of Sardina pilchardus on the northwest coast of the Iberian peninsula. Under both strong upwelling (low $Q_{X} F$ ) and low upwelling conditions (high $Q_{X} F$ ) in February, recruitment is low, probably due to strong winds producing a strongly mixed upper layer, which could have a detrimental effect on spring bloom primary production and/or on larval food aggregation. It is not possible to reject the hypothesis that the reduced recruitment success under low upwelling conditions (high $Q_{X}$ ) might also be due to strong southerly winds, leading to a low input of nutrients into the euphotic layers. Under moderate winds in February, recruitment success could be high if: upwelling intensity was high during the upwelling season (from May to August) over the preceding year, climatic conditions favor primary production (low NAO) and, finally, larval drift offshore in March and April is low.

As mentioned by Lasker (1978), to manage a fishery, it is necessary to predict whether and to what degree any particular spawning will result in successful recruitment. In this case, as a high proportion of its recruitment variability can be explained by a few factors, it would appear possible to predict the recruitment success of this pelagic fish species (Sardina pilchardus) in this particular area (northwest Iberian peninsula).
Acknowledgements. We thank the División de Operaciones Pesqueras de la Autoridad Portuaria de Vigo for supplying the landings of adult and juvenile sardines. This research was supported by the project MAR99-0328-C03-01, a grant from Fundación Provigo to I.R. and a grant from AECI to A.R.

\section{LITERATURE CITED}

Bailey KM (1981) Larval transport and recruitment of Pacific hake Merluccius productus. Mar Ecol Prog Ser 6:1-9

Bakun A (1973) Coastal upwelling indices, west coast of North America, 1946-1971. US Dept Commerce, Seattle, WA, NOAA Tech Rep NMFS SSRF-671

Bakun A, Parrish RH (1982) Turbulence, transport and pelagic fish in the California and Peru current system. CALCOFI (Calif Coop Ocean Fish Investig) Rep 23:99-112

Belvèze H, Erzini K (1983) The influence of hydroclimatic factors on the availability of the sardine (Sardina pilchardus, Walbaum) in the Moroccan Atlantic fishery. In: Sharp GD, Csirke J (ed) Proceedings of the expert consultation to examine changes in abundance and species composition of neritic fish resources. FIRM/R 291 (2), FAO, Rome, p 285-327

Borja A, Uriarte A, Valencia V, Motos L, Uriarte A (1996) Relationships between anchovy (Engraulis encrasicolus L.) recruitment and the environment in the Bay of Biscay. Sci Mar 60(Suppl 2):179-192

Canino MF, Bailey KM, Incze LS (1991) Temporal and geographic differences in feeding and nutritional condition of walleye pollock larvae Theragra chalcogramma in Shelikof Strait, Gulf of Alaska. Mar Ecol Prog Ser 79:27-35

Chesney EJ, Alonso-Noval M (1988) The role of physical oceanographic processes in the early life history of sardines, Sardina pilchardus, along the Galician coast of Spain. ICES Early Life History Symposium 25:1-15

Cury P, Roy C (1989) Optimal environmental window and pelagic fish recruitment success in upwelling areas. Can J Fish Aquat Sci 46:670-680

Cushing DH (1975) Marine ecology and fisheries. Cambridge University Press, Cambridge

Dickson RR, Kelly PM, Colebrook JM, Wooster WS, Cushing $\mathrm{DH}$ (1988) North winds and production in the eastern North Atlantic. J Plankton Res 10:151-169

Ferreiro MJ, Labarta U (1988) Distribution and abundance of sardine eggs in the Ria of Vigo (NW Spain), 1979-1984. J Plankton Res 10:403-412

García A, Franco C, Solá A, Alonso M, Rodríguez JM (1988) Distribution of sardine (Sardine pilchardus, Walb.) egg and larval abundances off the Spanish North Atlantic coasts (Galician and Cantabrian areas) in April, 1987. CM ICES (Demersal Fish Comm) H:21:1-13

Hjort J (1914) Fluctuations in the great fisheries of northern Europe viewed in the light of biological research. Rapp P-V Reun Cons Perm Int Explor Mer 20:1-228

Huntsman SA, Barber RT (1977) Primary production off northwest Africa: the relationship to wind and nutrient conditions. Deep-Sea Res 24:25-33

Hurrel JW (1995) Decadal trends in the North Atlantic Oscillation: regional temperatures and precipitation. Science 269:676-679

Kitahara EM, Matsuura Y (1995) Growth mortality estimate of the southwest Atlantic anchovy Engraulis anchoita larvae from Cape Santa Marta Grande in southern Brazil. Arch Fish Mar Res 42:251-262

Lasker R (1978) The relationship between oceanographic conditions and larval anchovy food in the California 
current: identification of factors contributing to recruitment failure. Rapp P-V Reun Cons Int Explor Mer 173: 212-230

Lasker R (1981) Marine fish larvae. Morphology, ecology, and relation to fisheries. University of Washington Press, Seattle

Lavín A, Díaz del Río G, Cabanas JM, Casas G (1991) Afloramiento en el noroeste de la Península Ibérica. Indices de Afloramiento para el punto $43^{\circ} \mathrm{N} 11^{\circ} \mathrm{W}$. Período $1966-$ 1989. Inf Tec Inst Esp Oceanogr 91:1-40

López-Jamar E, Coombs SH, García A, Halliday NC, Knust R, Nellen W (1995) The distribution and survival of larvae of Sardine pilchardus (Walbaum, 1972) off the north and north-western Atlantic coast of the Iberian Peninsula, in relation to environmental conditions. Bol Inst Esp Oceanogr 11:27-46

Mann KH, Lazier JRN (1991) Dynamics of marine ecosystems. Blackwell, Oxford

Marshall CT, Frank KT (1999) The effect of interannual variation in growth and condition on haddock recruitment. Can J Fish Aquat Sci 56:347-355

Parrish RC, Nelson CS, Bakun A (1981) Transport mechanisms and reproductive success of fishes in the California Current. Biol Oceanogr 1:175-203

Peterman MR, Bradford MJ (1987) Wind speed and mortality rate of a marine fish, the northern anchovy (Engraulis mordax). Science 235:354-356

Ré P, Cabral e Silva R, Cunha E, Farinha A, Meneses I, Moita

Editorial responsibility: Otto Kinne (Editor),

Oldendorf/Luhe, Germany
T (1990) Sardine spawning off Portugal. Bol Inst Nac Investig Pesca 15:31-44

Riveiro I, Guisande C, Lloves M, Maneiro I, Cabanas JM (2000) Importance of parental effects in larval survival in Sardina pilchardus. Mar Ecol Prog Ser 205:249-258

Robles R, Porteiro C, Cabanas JM (1992) The stock of AtlantoIberian sardine: possible causes of variability. ICES Mar Sci Symp 195:418-423

Sinclair M, Tremblay ML, Bernal P (1985) El Niño events and variability in Pacific Mackerel (Scomber japonicus) survival index: support for Hjort's second hypothesis. Can J Fish Aquat Sci 42:602-608

Solá A, Franco C (1984) Ichthyoplankton survey of interesting commercial species of the Cantabric and Galician shelves (N. NW Spain). CM ICES (Demersal Fish Comm) H: 42:1-26

Tenore KR, Alvarez-Ossorio M, Atkinson LP, Cabanas JM and 15 others(1995) Fisheries and oceanography off Galicia, NW Spain (FOG): mesoscale spatial and temporal changes in physical processes and resultant patterns of biological productivity. J Geophys Res 100(c6):10943-10966

Theilacker GH (1986) Starvation-induced mortality of young sea-caught jack mackerel, Trachurus symmetricus, determined with histological and morphological methods. Fish Bull (Wash DC) 84:1-17

Wyatt T, Pérez-Gándaras G (1988) Ekman transport and sardine yields in western Iberia. In: International symposium on long term changes in marine fish populations. Vigo, p 125-138

Submitted: October 6, 2000; Accepted: March 15, 2001

Proofs received from author(s): November 19, 2001 